\title{
PENELITIAN
}

\section{FAKTOR-FAKTOR YANG BERHUBUNGAN DENGAN PERILAKU PENCARIAN PENGOBATAN PADA PRIA DENGAN PENYAKIT MENULAR SEKSUAL (PMS)-HIV/AIDS DI JAKARTA, SURABAYA DAN MENADO TAHUN 2000}

\author{
Efy Afifah *
}

\begin{abstract}
Abstrak
Masalah Penyakit Menular Seksual (PMS)-HIV/AIDS di Indonesia saat ini merupakan hal yang patut diwaspadai dan diantisipasi lebih dini, mengingat prevalensinya yang meningkat. Salah satu faktor yang berperan dalam penanggulangan PMS-HIV/AIDS adalah perilaku pencarian pengobatan yang masih rendah khususnya pada kelompok pria.

Tujuan penelitian ini adalah untuk mengetahui faktor-faktor yang berhubungan dengan perilaku pencarian pengobatan pada pria dengan PMS-HIV/AIDS di Jakarta, Surabaya, dan Menado. Rancangan penelitian ini adalah deskriptif dengan menggunakan pendekatan studi potong lintang (cross sectional), dengan pengolahan data menggunakan analisis regresi logistik ganda yang menggunakan data Behavioral Surveillance Survey PMS-HIV/AIDS tahun 2000. Jumlah sampel yang terlibat 624 responden. Hasil penelitian ini menunjukkan 75,3\% proporsi perilaku pencarian pengobatan kurang baik. Tidak ada hubungan yang bermakna antara umur, status perkawinan, sumber informasi dengan perilaku pencarian pengobatan. Variabel pengetahuan dan pendidikan berhubungan secara bermakna dengan perilaku pencarian pengobatan dan tidak ada interaksi antara pendidikan dan pengetahuan. Responden yang berpengetahuan kurang berpeluang 1,8 kali (95\% CI: 1,1724-2,6442) melakukan pencarian pengobatan kurang baik dibandingkan dengan responden yang berpengetahuan baik setelah dikontrol variabel pendidikan. Responden yang berpendidikan rendah berpeluang $1,7 \mathrm{kali}(95 \% \mathrm{CI}$ : 1,0236- 2,5805) melakukan pencarian pengobatan kurang baik dibandingkan responden yang berpendidikan tinggi setelah dikontrol variabel pengetahuan. Rekomendasi telah disampaikan pada pemerintah untuk menjadikan program tetap dan pengalokasian dana tidak hanya untuk pengobatan juga untuk pelayanan kesehatan dan konseling dan penelitian lebih lanjut untuk menggali lebih dalam alasan responden yang tidak melakukan pencarian pengobatan perlu pula untuk dilakukan.
\end{abstract}

Kata kunci: perilaku pencarian pengobatan pria, STD-HIV/AIDS

\begin{abstract}
Currenly, a sexual transmitted disease (STD)-HIV/AIDS in Indonesia, is an issue that every individual should concern and anticipate, this is because its prevalency increases. The strategic position of Indonesia is considered susceptible to the pandemy of HIVI AIDS. One of the factors which play an important role in controlling the STD-HIV/AIDS is a low rate health seeking behaviour among male subjects. The purpose of the study was to identify factors influencing to health seeking behaviour of male subjects with STD-HIV/AIDS in Jakarta, Surabaya, and Manado. The design of the study was descriptive explorative using cross sectional approach. A multiple logistic regression was used to analyse the secondary data from behavioral surveillance survey of STD-HIVI AIDS in 2000. The number of sampel was 624 respondents. The findings showed that the proportion of male health seeking behaviour is low $(75,3 \% N=624)$. There are no relationships between age, marital status, and information sources with the health seeking behaviour. The variables of education and knowledge have relationship with health seeking behaviour and there is no interaction between education and knowledge. Respondents with limited knowledge have the possibilities 1.8 times to have poor health seeking behaviour (95\% CI: 1, 1725 - 2, 6442) compared to those who have sufficient knowledge after being controlled by the education variable. Respondents who have lower education have the possibilities of 1,7 times to have poor health seeking behaviour ( 95\% CI: 1,00236 - 2,5805) compared to those who have higher education after being controlled by knowledge variable. Some recommendations were contributed to government to create the prevention program of STD-HIV/AIDS as an annual program and to allocate fund which is not only for medication but also for the health and counseling services. Further study needs to be done to explore more detailed explanations why respondents do not seek for health care.
\end{abstract}

Key words: health seeking behaviour male, STD-HIV/AIDS 


\title{
PENELITIAN
}

\section{FAKTOR-FAKTOR YANG BERHUBUNGAN DENGAN PERILAKU PENCARIAN PENGOBATAN PADA PRIA DENGAN PENYAKIT MENULAR SEKSUAL (PMS)-HIV/AIDS DI JAKARTA, SURABAYA DAN MENADO TAHUN 2000}

\author{
Efy Afifah *
}

\begin{abstract}
Abstrak
Masalah Penyakit Menular Seksual (PMS)-HIV/AIDS di Indonesia saat ini merupakan hal yang patut diwaspadai dan diantisipasi lebih dini, mengingat prevalensinya yang meningkat. Salah satu faktor yang berperan dalam penanggulangan PMS-HIV/AIDS adalah perilaku pencarian pengobatan yang masih rendah khususnya pada kelompok pria.

Tujuan penelitian ini adalah untuk mengetahui faktor-faktor yang berhubungan dengan perilaku pencarian pengobatan pada pria dengan PMS-HIV/AIDS di Jakarta, Surabaya, dan Menado. Rancangan penelitian ini adalah deskriptif dengan menggunakan pendekatan studi potong lintang (cross sectional), dengan pengolahan data menggunakan analisis regresi logistik ganda yang menggunakan data Behavioral Surveillance Survey PMS-HIV/AIDS tahun 2000. Jumlah sampel yang terlibat 624 responden. Hasil penelitian ini menunjukkan 75,3\% proporsi perilaku pencarian pengobatan kurang baik. Tidak ada hubungan yang bermakna antara umur, status perkawinan, sumber informasi dengan perilaku pencarian pengobatan. Variabel pengetahuan dan pendidikan berhubungan secara bermakna dengan perilaku pencarian pengobatan dan tidak ada interaksi antara pendidikan dan pengetahuan. Responden yang berpengetahuan kurang berpeluang 1,8 kali (95\% CI: 1,1724-2,6442) melakukan pencarian pengobatan kurang baik dibandingkan dengan responden yang berpengetahuan baik setelah dikontrol variabel pendidikan. Responden yang berpendidikan rendah berpeluang $1,7 \mathrm{kali}(95 \% \mathrm{CI}$ : 1,0236- 2,5805) melakukan pencarian pengobatan kurang baik dibandingkan responden yang berpendidikan tinggi setelah dikontrol variabel pengetahuan. Rekomendasi telah disampaikan pada pemerintah untuk menjadikan program tetap dan pengalokasian dana tidak hanya untuk pengobatan juga untuk pelayanan kesehatan dan konseling dan penelitian lebih lanjut untuk menggali lebih dalam alasan responden yang tidak melakukan pencarian pengobatan perlu pula untuk dilakukan.
\end{abstract}

Kata kunci: perilaku pencarian pengobatan pria, STD-HIV/AIDS

\begin{abstract}
Currenly, a sexual transmitted disease (STD)-HIV/AIDS in Indonesia, is an issue that every individual should concern and anticipate, this is because its prevalency increases. The strategic position of Indonesia is considered susceptible to the pandemy of HIVI AIDS. One of the factors which play an important role in controlling the STD-HIV/AIDS is a low rate health seeking behaviour among male subjects. The purpose of the study was to identify factors influencing to health seeking behaviour of male subjects with STD-HIV/AIDS in Jakarta, Surabaya, and Manado. The design of the study was descriptive explorative using cross sectional approach. A multiple logistic regression was used to analyse the secondary data from behavioral surveillance survey of STD-HIVI AIDS in 2000. The number of sampel was 624 respondents. The findings showed that the proportion of male health seeking behaviour is low $(75,3 \% N=624)$. There are no relationships between age, marital status, and information sources with the health seeking behaviour. The variables of education and knowledge have relationship with health seeking behaviour and there is no interaction between education and knowledge. Respondents with limited knowledge have the possibilities 1.8 times to have poor health seeking behaviour (95\% CI: 1, 1725 - 2, 6442) compared to those who have sufficient knowledge after being controlled by the education variable. Respondents who have lower education have the possibilities of 1,7 times to have poor health seeking behaviour ( 95\% CI: 1,00236 - 2,5805) compared to those who have higher education after being controlled by knowledge variable. Some recommendations were contributed to government to create the prevention program of STD-HIV/AIDS as an annual program and to allocate fund which is not only for medication but also for the health and counseling services. Further study needs to be done to explore more detailed explanations why respondents do not seek for health care.
\end{abstract}

Key words: health seeking behaviour male, STD-HIV/AIDS 


\section{LATAR BELAKANG}

Masalah Penyakit Menular Seksual (PMS) sampai saat ini masih merupakan masalah kesehatan masyarakat di seluruh dunia, namun baik insidens maupun prevalensi yang sebenarnya di berbagai negara tidak diketahui dengan pasti. Penyakit Menular Seksual (PMS) dan Human Immunodeficiency Virus/ Acquired Immuno Deficiency Syndrom (HIV/AIDS) merupakan dua masalah yang tidak dapat dipisahkan satu sama lain.

Ditjen PPM \& PL tahun 2002 melaporkan prevalensi AIDS Nasional sampai 30 Juni 2002 adalah 0,36 per 100.000 penduduk. Kasus HIV/ AIDS terus bertambah sejak ditemukannya kasus pertama AIDS di Indonesia pada tahun 1987, yaitu ketika seorang turis Belanda homoseks meninggal di Bali, kemudian meningkat hingga akhir Juni 2002 telah mencapai 2950 kasus HIV/AIDS (Depkes RI, 2002).

Beberapa golongan yang berisiko tinggi terinfeksi HIV/AIDS tersebut meliputi: homoseksual dan heteroseksual, praktik injeksi dan sterilisasi alat kedokteran yang tidak memenuhi persyaratan, ras tertentu (Haiti/Afrika), hemofilia dan penyakit yang pengobatannya sering ditransfusi, serta janin yang dikandung oleh ibu berpenyakit HIV/ AIDS (Oetomo, 2001). Peningkatan kasus HIV/AIDS secara cepat di Indonesia disebabkan adanya faktor pemicu seperti perilaku seks bebas, kemiskinan, pengguna narkoba suntikan, urbanisasi dan migrasi penduduk yang tinggi, lalu lintas dari dan ke luar negeri serta peningkatan kasus penyakit kelamin (Depkes RI, 1997).

Dari berbagai cara penularan, transmisi seksual memainkan peran yang dominan dalam penyebaran penyakit. Selain itu terdapat korelasi yang tinggi antara seropositive HIV dan riwayat yang lalu dengan penyakit ulcer pada genital (sebagian besar chancroid) di Amerika Serikat dan Afrika (Akinnawo \& Oguntimehin, 1997). Kaitan antara PMS dengan HIV/AIDS mengakibatkan pentingnya upaya penanggulangan HIV/AIDS.

Upaya penanggulangan HIV/AIDS terus diupayakan di dunia secara terpadu dengan strategi mempertegas tantangan untuk melawan HIV/AIDS secara global. Hal ini sejalan dengan strategi nasional penanggulangan HIV/AIDS melalui Keputusan Presiden (Keppres 36/94), untuk memperkuat ketahanan keluarga (Muninjaya, 1999).

Kelompok pria berisiko tinggi HIV/AIDS termasuk supir truk dan asisten, pekerja pelabuhan, dan pelaut memberikan kontribusi yang besar dalam penularan penyakit. Adanya faktor-faktor seperti cenderung berpindah-pindah, menetap di suatu tempat dalam periode yang singkat, sering meninggalkan keluarga menjadi alasan keengganan untuk mencari pengobatan. Sebaliknya salah satu faktor yang berperan dalam penanggulangan PMS-HIV/AIDS adalah perilaku pencarian pengobatan. Persentase pasien pria $(60 \%)$ yang berobat lebih rendah dari pasien wanita $(78 \%)$, hasil studi pada pria remaja dan dewasa muda di perkampungan kumuh Jakarta (Suryadi, 2000).

Berdasarkan kondisi di atas, penelitian ini bertujuan untuk mengetahui faktor-faktor yang berhubungan dengan perilaku pencarian pengobatan pada pria dengan PMS-HIV/AIDS yang diwakili oleh supir truk dan asisten, pekerja pelabuhan dan pelaut di Jakarta, Surabaya, dan Menado tahun 2000. Pertimbangan digunakannya ketiga kota ini adalah karena kasus HIV/AIDS di ketiga kota tersebut tinggi, yaitu di Jakarta 292 kasus $(38,83 \%)$, Jawa Timur 64 kasus $(8,51 \%)$, dan Sulawesi Utara 14 kasus $(1,86 \%)$ serta alur masuk pelabuhan utama yang sangat aktif industri komersialisasi seksnya. 


\section{LATAR BELAKANG}

Masalah Penyakit Menular Seksual (PMS) sampai saat ini masih merupakan masalah kesehatan masyarakat di seluruh dunia, namun baik insidens maupun prevalensi yang sebenarnya di berbagai negara tidak diketahui dengan pasti. Penyakit Menular Seksual (PMS) dan Human Immunodeficiency Virus/ Acquired Immuno Deficiency Syndrom (HIV/AIDS) merupakan dua masalah yang tidak dapat dipisahkan satu sama lain.

Ditjen PPM \& PL tahun 2002 melaporkan prevalensi AIDS Nasional sampai 30 Juni 2002 adalah 0,36 per 100.000 penduduk. Kasus HIV/ AIDS terus bertambah sejak ditemukannya kasus pertama AIDS di Indonesia pada tahun 1987, yaitu ketika seorang turis Belanda homoseks meninggal di Bali, kemudian meningkat hingga akhir Juni 2002 telah mencapai 2950 kasus HIV/AIDS (Depkes RI, 2002).

Beberapa golongan yang berisiko tinggi terinfeksi HIV/AIDS tersebut meliputi: homoseksual dan heteroseksual, praktik injeksi dan sterilisasi alat kedokteran yang tidak memenuhi persyaratan, ras tertentu (Haiti/Afrika), hemofilia dan penyakit yang pengobatannya sering ditransfusi, serta janin yang dikandung oleh ibu berpenyakit HIV/ AIDS (Oetomo, 2001). Peningkatan kasus HIV/AIDS secara cepat di Indonesia disebabkan adanya faktor pemicu seperti perilaku seks bebas, kemiskinan, pengguna narkoba suntikan, urbanisasi dan migrasi penduduk yang tinggi, lalu lintas dari dan ke luar negeri serta peningkatan kasus penyakit kelamin (Depkes RI, 1997).

Dari berbagai cara penularan, transmisi seksual memainkan peran yang dominan dalam penyebaran penyakit. Selain itu terdapat korelasi yang tinggi antara seropositive HIV dan riwayat yang lalu dengan penyakit ulcer pada genital (sebagian besar chancroid) di Amerika Serikat dan Afrika (Akinnawo \& Oguntimehin, 1997). Kaitan antara PMS dengan HIV/AIDS mengakibatkan pentingnya upaya penanggulangan HIV/AIDS.

Upaya penanggulangan HIV/AIDS terus diupayakan di dunia secara terpadu dengan strategi mempertegas tantangan untuk melawan HIV/AIDS secara global. Hal ini sejalan dengan strategi nasional penanggulangan HIV/AIDS melalui Keputusan Presiden (Keppres 36/94), untuk memperkuat ketahanan keluarga (Muninjaya, 1999).

Kelompok pria berisiko tinggi HIV/AIDS termasuk supir truk dan asisten, pekerja pelabuhan, dan pelaut memberikan kontribusi yang besar dalam penularan penyakit. Adanya faktor-faktor seperti cenderung berpindah-pindah, menetap di suatu tempat dalam periode yang singkat, sering meninggalkan keluarga menjadi alasan keengganan untuk mencari pengobatan. Sebaliknya salah satu faktor yang berperan dalam penanggulangan PMS-HIV/AIDS adalah perilaku pencarian pengobatan. Persentase pasien pria $(60 \%)$ yang berobat lebih rendah dari pasien wanita $(78 \%)$, hasil studi pada pria remaja dan dewasa muda di perkampungan kumuh Jakarta (Suryadi, 2000).

Berdasarkan kondisi di atas, penelitian ini bertujuan untuk mengetahui faktor-faktor yang berhubungan dengan perilaku pencarian pengobatan pada pria dengan PMS-HIV/AIDS yang diwakili oleh supir truk dan asisten, pekerja pelabuhan dan pelaut di Jakarta, Surabaya, dan Menado tahun 2000. Pertimbangan digunakannya ketiga kota ini adalah karena kasus HIV/AIDS di ketiga kota tersebut tinggi, yaitu di Jakarta 292 kasus $(38,83 \%)$, Jawa Timur 64 kasus $(8,51 \%)$, dan Sulawesi Utara 14 kasus $(1,86 \%)$ serta alur masuk pelabuhan utama yang sangat aktif industri komersialisasi seksnya. 


\section{METODOLOGI}

Penelitian ini menggunakan data Behavioral Surveillance Surveys (BSS) tahun 2000 pada pria dengan PMS-HIV/AIDS di Jakarta, Surabaya, Menado. Pengumpulan data dilakukan Pusat Penelitian Kesehatan Universitas Indonesia (PPKUI) dengan menggunakan desain cross sectional. Populasi target penelitian ini didasarkan pada sentinel assessment kelompok berisiko yaitu supir truk dan asisten, pekerja pelabuhan dan pelaut di Jakarta Utara, Surabaya dan Menado (Bitung). Pemilihan sampel dilakukan melalui tahap mapping, dengan cara mengidentifikasi tempat, menentukan nama lokasi, jumlah populasi/ hari, memilih lokasi dengan cara identifikasi keberadaan sasaran dan jumlah sampel di tiap lokasi terpilih dengan cara random menggunakan Probability Proportionate to Size (PPS). Pada studi ini digunakan hanya jumlah sampel pria dengan PMS-HIV/AIDS sebesar 624 orang. Proses analisis yang dilakukan adalah univariat, bivariat dan multivariat (menggunakan program Multiple Logisic Regression).

\section{HASIL}

Hasil penelitian yang disajikan berikut ini terdiri dari karakteristik sosio demografi, pengetahuan dan sumber informasi. Dari hasil univariat didapatkan paling banyak $58,8 \%$ responden berumur muda (< 31 tahun), lebih dari setengah responden 64,3\% sudah kawin dan lebih dari setengah responden $(66,5 \%)$ berpendidikan tinggi (tamat SLTA, Akademi / Perguruan Tinggi). Mereka umumnya $(98,6 \%)$ pernah mendengar atau berbincang dengan seseorang mengenai AIDS. Dari tabel 1. dapat dilihat $54,5 \%$ responden berpengetahuan kurang.

Tabel 1

Distribusi Frekuensi Responden Menurut Pengetahuan Menurut Kategori Di Jakarta, Surabaya dan Menado, 2000

\begin{tabular}{lcr}
\hline \multicolumn{1}{c}{ Pengetahuan } & $\mathrm{n}$ & $\%$ \\
\hline Pengetahuan kurang & 340 & 54,5 \\
Pengetahuan baik & 284 & 45,5 \\
Total & 624 & 100,0 \\
\hline
\end{tabular}

Sumber informasi tentang AIDS selama sebulan terakhir mencakup media massa dan media elektronik, menunjukkan sebesar 57,9\% responden pernah melihat di televisi, $49,8 \%$ responden membaca di surat kabar, dan 36,7\% responden mendengarkan radio, dan paling sedikit $27,9 \%$ responden pernah membaca di majalah. Selain itu 55,13\% responden pernah kontak media. Prosentase responden yang melakukan upaya pengobatan sendiri adalah $74,2 \%$, dan mencari pertolongan medis $59,3 \%$. Dari seluruh sampel (624 responden) sebagian besar $75,3 \%$ berperilaku kurang baik (tabel 2.)

Tabel 2

Distribusi Frekuensi Responden Menurut Perilaku Pencarian Pengobatan Berdasarkan Kategori Di Jakarta, Surabaya dan Menado, 2000

\begin{tabular}{lcr}
\hline Kategori Perilaku & $\mathrm{n}$ & $\%$ \\
\hline Baik & 154 & 24,7 \\
Kurang baik & 470 & 75,3 \\
Total & 624 & 100,0 \\
\hline
\end{tabular}

Hasil analisis hubungan antara umur dengan perilaku pencarian pengobatan pada pria dengan PMS-HIV/AIDS didapatkan bahwa diantara 367 responden yang berumur $<31$ tahun sebanyak 300 $(81,7 \%)$ yang berperilaku pencarian pengobatan kurang baik sedangkan dari 257 responden yang berumur $>31$ tahun hanya $202(78,6 \%)$ yang berperilaku pencarian pengobatan kurang baik. Hasil uji beda proporsi dengan chi-square, $\mathrm{x}^{2}=$ 0,950 dan $p=0,191(p>0,05)$, berarti tidak ada perbedaan proporsi perilaku pencarian pengobatan antara responden yang berumur muda dibandingkan responden yang berumur tua. Nilai OR $=1,219$ (95\%: 0,818-1,816), artinya responden yang berumur $<31$ tahun berpeluang 1,219 kali melakukan pencarian pengobatan kurang baik dibandingkan responden yang berumur $>30$ tahun.

Hasil analisis hubungan antara status perkawinan dengan perilaku pencarian pengobatan pada pria dengan PMS-HIV/AIDS 


\section{METODOLOGI}

Penelitian ini menggunakan data Behavioral Surveillance Surveys (BSS) tahun 2000 pada pria dengan PMS-HIV/AIDS di Jakarta, Surabaya, Menado. Pengumpulan data dilakukan Pusat Penelitian Kesehatan Universitas Indonesia (PPKUI) dengan menggunakan desain cross sectional. Populasi target penelitian ini didasarkan pada sentinel assessment kelompok berisiko yaitu supir truk dan asisten, pekerja pelabuhan dan pelaut di Jakarta Utara, Surabaya dan Menado (Bitung). Pemilihan sampel dilakukan melalui tahap mapping, dengan cara mengidentifikasi tempat, menentukan nama lokasi, jumlah populasi/ hari, memilih lokasi dengan cara identifikasi keberadaan sasaran dan jumlah sampel di tiap lokasi terpilih dengan cara random menggunakan Probability Proportionate to Size (PPS). Pada studi ini digunakan hanya jumlah sampel pria dengan PMS-HIV/AIDS sebesar 624 orang. Proses analisis yang dilakukan adalah univariat, bivariat dan multivariat (menggunakan program Multiple Logisic Regression).

\section{HASIL}

Hasil penelitian yang disajikan berikut ini terdiri dari karakteristik sosio demografi, pengetahuan dan sumber informasi. Dari hasil univariat didapatkan paling banyak $58,8 \%$ responden berumur muda (< 31 tahun), lebih dari setengah responden 64,3\% sudah kawin dan lebih dari setengah responden $(66,5 \%)$ berpendidikan tinggi (tamat SLTA, Akademi / Perguruan Tinggi). Mereka umumnya $(98,6 \%)$ pernah mendengar atau berbincang dengan seseorang mengenai AIDS. Dari tabel 1. dapat dilihat $54,5 \%$ responden berpengetahuan kurang.

Tabel 1

Distribusi Frekuensi Responden Menurut Pengetahuan Menurut Kategori Di Jakarta, Surabaya dan Menado, 2000

\begin{tabular}{lcr}
\hline \multicolumn{1}{c}{ Pengetahuan } & $\mathrm{n}$ & $\%$ \\
\hline Pengetahuan kurang & 340 & 54,5 \\
Pengetahuan baik & 284 & 45,5 \\
Total & 624 & 100,0 \\
\hline
\end{tabular}

Sumber informasi tentang AIDS selama sebulan terakhir mencakup media massa dan media elektronik, menunjukkan sebesar 57,9\% responden pernah melihat di televisi, $49,8 \%$ responden membaca di surat kabar, dan 36,7\% responden mendengarkan radio, dan paling sedikit $27,9 \%$ responden pernah membaca di majalah. Selain itu 55,13\% responden pernah kontak media. Prosentase responden yang melakukan upaya pengobatan sendiri adalah $74,2 \%$, dan mencari pertolongan medis $59,3 \%$. Dari seluruh sampel (624 responden) sebagian besar $75,3 \%$ berperilaku kurang baik (tabel 2.)

Tabel 2

Distribusi Frekuensi Responden Menurut Perilaku Pencarian Pengobatan Berdasarkan Kategori Di Jakarta, Surabaya dan Menado, 2000

\begin{tabular}{lcr}
\hline Kategori Perilaku & $\mathrm{n}$ & $\%$ \\
\hline Baik & 154 & 24,7 \\
Kurang baik & 470 & 75,3 \\
Total & 624 & 100,0 \\
\hline
\end{tabular}

Hasil analisis hubungan antara umur dengan perilaku pencarian pengobatan pada pria dengan PMS-HIV/AIDS didapatkan bahwa diantara 367 responden yang berumur $<31$ tahun sebanyak 300 $(81,7 \%)$ yang berperilaku pencarian pengobatan kurang baik sedangkan dari 257 responden yang berumur $>31$ tahun hanya $202(78,6 \%)$ yang berperilaku pencarian pengobatan kurang baik. Hasil uji beda proporsi dengan chi-square, $\mathrm{x}^{2}=$ 0,950 dan $p=0,191(p>0,05)$, berarti tidak ada perbedaan proporsi perilaku pencarian pengobatan antara responden yang berumur muda dibandingkan responden yang berumur tua. Nilai OR $=1,219$ (95\%: 0,818-1,816), artinya responden yang berumur $<31$ tahun berpeluang 1,219 kali melakukan pencarian pengobatan kurang baik dibandingkan responden yang berumur $>30$ tahun.

Hasil analisis hubungan antara status perkawinan dengan perilaku pencarian pengobatan pada pria dengan PMS-HIV/AIDS 
didapatkan bahwa responden yang belum kawin berpeluang berperilaku pencarian pengobatan kurang baik sebesar $83 \%$, sedangkan responden yang kawin memiliki peluang lebih rendah untuk berperilaku pencarian pengobatan kurang baik, yaitu sebesar 79,1\%. Hasil uji beda proporsi menunjukkan nilai $\mathrm{p}=0,119$, berarti pada $\alpha=$ $5 \%$ tidak ada perbedaan proporsi perilaku pencarian pengobatan antara responden yang belum kawin dan kawin. Nilai OR = 1,290 (95\%: 0,844-1,971), yang berarti responden yang belum kawin berpeluang 1,290 kali melakukan pencarian pengobatan kurang baik dibandingkan responden yang kawin.

Hasil analisis hubungan antara pendidikan dengan perilaku pencarian pengobatan pada pria dengan PMS-HIV/AIDS, responden dengan pendidikan rendah berpeluang melakukan pencarian pengobatan kurang baik sebanyak 180 $(86,1 \%)$. Sedangkan responden dengan pendidikan tinggi memiliki peluang lebih rendah, yaitu sebanyak 322 (77,6\%).Dari hasil uji beda proporsi dengan chi-square, $\mathrm{x}^{2}=6,436$ dan $\mathrm{p}=$ $0,0055$ ( $\mathrm{p}<0,05)$, yang berarti ada hubungan bermakna antara responden berpendidikan rendah dengan perilaku pencarian pengobatan kurang baik, dengan OR = 1,793 (95\% CI: 1,137-2,826), responden yang berpendidikan rendah berpeluang melakukan pencarian pengobatan kurang baik 1,793 kali dibandingkan responden yang berpendidikan tinggi.

Hasil analisis hubungan antara pengetahuan dengan perilaku pencarian pengobatan pada pria dengan PMS-HIV/AIDS didapatkan bahwa 284 (85\%) dari 340 responden yang berpengetahuan kurang, memiliki perilaku pencarian pengobatan kurang baik dan 213 (75\%) dari 284 responden yang berpengetahuan baik berperilaku pencarian pengobatan kurang baik Hasil uji beda proporsi dengan chi-square, $\mathrm{x}^{2}=9,838 \quad \mathrm{p}=0,01 \quad(\mathrm{p}<$ $0,05)$, berarti ada hubungan yang bermakna antara yang berpengetahuan kurang baik dengan perilaku pencarian pengobatan kurang baik.
Hasil analisis hubungan antara sumber informasi dengan perilaku pencarian pengobatan pada pria dengan PMS-HIV/AIDS. Responden yang tidak pernah kontak dengan sumber informasi berpeluang melakukan pencarian pengobatan kurang baik sebesar 277 (80,5\%). Selanjutnya dari hasil uji beda proporsi dengan chi square, $\mathrm{x}^{2}=0,003$ dan $\mathrm{p}=0,5 \quad(\mathrm{p}>0,05)$, berarti tidak ada perbedaan proporsi perilaku pencarian pengobatan antara responden yang tidak pernah kontak dengan sumber informasi dibandingkan responden yang pernah kontak sumber informasi. Nilai OR=1,011 (95\% CI: 0,679-1,504), artinya responden yang tidak pernah kontak dengan sumber informasi berpeluang melakukan pencarian pengobatan kurang baik 1,011 kali dibandingkan mereka yang pernah kontak dengan sumber informasi.

Tahapan analisis multivariat meliputi pemilihan variabel kandidat multivariat, pembuatan model dan analisis interaksi. Variabel yang terus masuk ke model multivariat yaitu pendidikan dan pengetahuan.. Dari uji interaksi tidak terlihat adanya interaksi antara pendidikan dan pengetahuan ( $p$ value $=0,3520)$, berarti bahwa hubungan pendidikan dengan perilaku pencarian pengobatan tidak memberikan efek yang berbeda antara responden yang berpengetahuan kurang dan responden yang berpengetahuan baik.

Tabel 3

Hasil Analisis Multivariat Regresi Logistik Antara Pendidikan dan Pengetahuan

Dengan Perilaku Pencarian Pengobatan

\begin{tabular}{lcccc}
\hline Variabel & B & P wald & OR & CI \\
\hline Pendidikan & 0,4857 & 0,0395 & 1,6252 & $1,0236-2,5805$ \\
Pengetahuan & 0,5657 & 0,0064 & 1,7607 & $1,1724-2,6442$ \\
Constant & -20414 & 0,0000 & & \\
\hline
\end{tabular}

Dari tabel di atas, responden yang berpengetahuan kurang berpeluang 1,760 kali (95 \% CI: 1,1724 - 2, 6442 untuk mencari pengobatan kurang baik dibandingkan dengan responden yang 
didapatkan bahwa responden yang belum kawin berpeluang berperilaku pencarian pengobatan kurang baik sebesar $83 \%$, sedangkan responden yang kawin memiliki peluang lebih rendah untuk berperilaku pencarian pengobatan kurang baik, yaitu sebesar 79,1\%. Hasil uji beda proporsi menunjukkan nilai $\mathrm{p}=0,119$, berarti pada $\alpha=$ $5 \%$ tidak ada perbedaan proporsi perilaku pencarian pengobatan antara responden yang belum kawin dan kawin. Nilai OR = 1,290 (95\%: 0,844-1,971), yang berarti responden yang belum kawin berpeluang 1,290 kali melakukan pencarian pengobatan kurang baik dibandingkan responden yang kawin.

Hasil analisis hubungan antara pendidikan dengan perilaku pencarian pengobatan pada pria dengan PMS-HIV/AIDS, responden dengan pendidikan rendah berpeluang melakukan pencarian pengobatan kurang baik sebanyak 180 $(86,1 \%)$. Sedangkan responden dengan pendidikan tinggi memiliki peluang lebih rendah, yaitu sebanyak 322 (77,6\%).Dari hasil uji beda proporsi dengan chi-square, $\mathrm{x}^{2}=6,436$ dan $\mathrm{p}=$ $0,0055$ ( $\mathrm{p}<0,05)$, yang berarti ada hubungan bermakna antara responden berpendidikan rendah dengan perilaku pencarian pengobatan kurang baik, dengan OR = 1,793 (95\% CI: 1,137-2,826), responden yang berpendidikan rendah berpeluang melakukan pencarian pengobatan kurang baik 1,793 kali dibandingkan responden yang berpendidikan tinggi.

Hasil analisis hubungan antara pengetahuan dengan perilaku pencarian pengobatan pada pria dengan PMS-HIV/AIDS didapatkan bahwa 284 (85\%) dari 340 responden yang berpengetahuan kurang, memiliki perilaku pencarian pengobatan kurang baik dan 213 (75\%) dari 284 responden yang berpengetahuan baik berperilaku pencarian pengobatan kurang baik Hasil uji beda proporsi dengan chi-square, $\mathrm{x}^{2}=9,838 \quad \mathrm{p}=0,01 \quad(\mathrm{p}<$ $0,05)$, berarti ada hubungan yang bermakna antara yang berpengetahuan kurang baik dengan perilaku pencarian pengobatan kurang baik.
Hasil analisis hubungan antara sumber informasi dengan perilaku pencarian pengobatan pada pria dengan PMS-HIV/AIDS. Responden yang tidak pernah kontak dengan sumber informasi berpeluang melakukan pencarian pengobatan kurang baik sebesar 277 (80,5\%). Selanjutnya dari hasil uji beda proporsi dengan chi square, $\mathrm{x}^{2}=0,003$ dan $\mathrm{p}=0,5 \quad(\mathrm{p}>0,05)$, berarti tidak ada perbedaan proporsi perilaku pencarian pengobatan antara responden yang tidak pernah kontak dengan sumber informasi dibandingkan responden yang pernah kontak sumber informasi. Nilai OR=1,011 (95\% CI: 0,679-1,504), artinya responden yang tidak pernah kontak dengan sumber informasi berpeluang melakukan pencarian pengobatan kurang baik 1,011 kali dibandingkan mereka yang pernah kontak dengan sumber informasi.

Tahapan analisis multivariat meliputi pemilihan variabel kandidat multivariat, pembuatan model dan analisis interaksi. Variabel yang terus masuk ke model multivariat yaitu pendidikan dan pengetahuan.. Dari uji interaksi tidak terlihat adanya interaksi antara pendidikan dan pengetahuan ( $p$ value $=0,3520)$, berarti bahwa hubungan pendidikan dengan perilaku pencarian pengobatan tidak memberikan efek yang berbeda antara responden yang berpengetahuan kurang dan responden yang berpengetahuan baik.

Tabel 3

Hasil Analisis Multivariat Regresi Logistik Antara Pendidikan dan Pengetahuan

Dengan Perilaku Pencarian Pengobatan

\begin{tabular}{lcccc}
\hline Variabel & B & P wald & OR & CI \\
\hline Pendidikan & 0,4857 & 0,0395 & 1,6252 & $1,0236-2,5805$ \\
Pengetahuan & 0,5657 & 0,0064 & 1,7607 & $1,1724-2,6442$ \\
Constant & -20414 & 0,0000 & & \\
\hline
\end{tabular}

Dari tabel di atas, responden yang berpengetahuan kurang berpeluang 1,760 kali (95 \% CI: 1,1724 - 2, 6442 untuk mencari pengobatan kurang baik dibandingkan dengan responden yang 
berpengetahuan baik setelah dikontrol variabel pendidikan. Responden yang berpendidikan rendah berpeluang 1,625 kali (95\% CI: 1,0236 2,5805 ) untuk melakukan pencarian pengobatan kurang baik dibandingkan responden yang berpendidikan tinggi setelah dikontrol variabel pengetahuan.

\section{PEMBAHASAN}

Tiga-per-empat $(75,3 \%)$ responden pria di ketiga kota tersebut tidak melakukan pencarian pengobatan, hal ini disebabkan oleh beberapa kemungkinan, seperti: menganggap gejala penyakitnya tidak parah, bukan ancaman bagi kehidupannya dan kondisi penyakit yang diderita tidak mengganggu pekerjaan sehari-hari sebagai supir truk, asisten, pelaut dan pekerja pelabuhan. Pada umumnya pria berpendapat lebih tahan terhadap suatu penyakit termasuk penyakit kelamin. Hal ini sesuai dengan penelitian Suryadi (2001) di Jakarta Utara pada pria dan dewasa muda yang berumur 15-24 tahun. Dari 16,7\% (n $=144$ ) terlihat penderita pria lebih cenderung tidak mengobati penyakitnya dibandingkan dengan penderita wanita ( $40 \%$ dan $24,3 \%$ ).

Rendahnya perilaku pria dalam melakukan pencarian pengobatan ini sangat mengkhawatirkan dan sangat besar pengaruhnya dalam penyebaran PMS-HIV/AIDS ternyata lebih banyak berstatus kawin (64,3\%). Kelompok pria tersebut termasuk dalam kelompok jembatan/ penghubung dalam penularan dari kelompok berisiko tinggi (wanita penjaja seks) pada kelompok berisiko rendah yaitu istri-istri mereka (Riono, 1999).

Dari 624 responden, sekitar seperempatnya $(24,7 \%)$ yang mencari pertolongan medis untuk mengatasi masalah $(59,3 \%)$ dan melakukan pengobatan sendiri $(74,2 \%)$. Setelah mencari pertolongan medis baru kemudian melakukan pengobatan sendiri (beli obat sendiri, ke dukun, menggunakan ramuan tradisional). Tahap-tahap pencarian pengobatan ini sesuai dengan hasil penelitian kualitatif di Jakarta Utara, dimana lebih dari seperempat responden di pelabuhan $(n=22)$, mengakui pernah sakit PMS. Tahap-tahap pencarian pengobatan ini berbeda menurut jenis penyakit kelamin (Kresno, 2001).

Sedangkan responden yang melakukan upaya pengobatan sendiri sebesar 74,2\%. Upaya untuk mengurangi gejala sakit ini sejalan dengan penelitian kualitatif di Jakarta Utara di mana mereka membeli obat antibiotik di warung atau toko obat seperti teramycin $500 \mathrm{mg}$ selama 5-7 hari dan baru berobat ke dokter bila tidak sembuh (Kresno, 2001). Oleh sebab itu besar kemungkinan responden menggunakan obat yang tidak tepat dan tidak sesuai dengan dosisnya sehingga perlu mendapat perhatian serius, karena dapat menimbulkan resistensi obat. Bertindak mengobati sendiri disebabkan sudah percaya kepada diri sendiri, dan meyakini akan mendapatkan kesembuhan (Notoatmodjo,1993).

Responden yang memanfaatkan pengobatan tradisional kemungkinan mengharapkan pengobatan yang lebih dari sekedar mendapat obat dan merasa kebutuhannya dapat terpenuhi. Pada umumnya masyarakat dalam mencari pertolongan kesehatan memanfaatkan pengobatan tradisional sebagai salah satu pilihannya. Dimulai dengan mencoba mengobati sendiri kemudian baru meminta pertolongan dukun. Hasilnya akan jauh lebih baik daripada tidak mengobati sama sekali (Soesilo,1992).

Di samping itu responden yang mencari pertolongan medis $(59,3 \%)$, kemungkinan disebabkan pada tahap peran sakit tidak ada kemajuan bila hanya mengobati sendiri (Kasl \& Cobb, 1983 dalam Becker \& Maiman,1983). Tidak adanya data tentang faktor-faktor yang menghambat dan mendorong individu untuk berobat ke pelayanan kesehatan pada penelitian ini, diasumsikan merupakan faktor keseriusan penyakit dan pelayanan kesehatan yang 
berpengetahuan baik setelah dikontrol variabel pendidikan. Responden yang berpendidikan rendah berpeluang 1,625 kali (95\% CI: 1,0236 2,5805 ) untuk melakukan pencarian pengobatan kurang baik dibandingkan responden yang berpendidikan tinggi setelah dikontrol variabel pengetahuan.

\section{PEMBAHASAN}

Tiga-per-empat $(75,3 \%)$ responden pria di ketiga kota tersebut tidak melakukan pencarian pengobatan, hal ini disebabkan oleh beberapa kemungkinan, seperti: menganggap gejala penyakitnya tidak parah, bukan ancaman bagi kehidupannya dan kondisi penyakit yang diderita tidak mengganggu pekerjaan sehari-hari sebagai supir truk, asisten, pelaut dan pekerja pelabuhan. Pada umumnya pria berpendapat lebih tahan terhadap suatu penyakit termasuk penyakit kelamin. Hal ini sesuai dengan penelitian Suryadi (2001) di Jakarta Utara pada pria dan dewasa muda yang berumur 15-24 tahun. Dari 16,7\% (n $=144$ ) terlihat penderita pria lebih cenderung tidak mengobati penyakitnya dibandingkan dengan penderita wanita ( $40 \%$ dan $24,3 \%$ ).

Rendahnya perilaku pria dalam melakukan pencarian pengobatan ini sangat mengkhawatirkan dan sangat besar pengaruhnya dalam penyebaran PMS-HIV/AIDS ternyata lebih banyak berstatus kawin (64,3\%). Kelompok pria tersebut termasuk dalam kelompok jembatan/ penghubung dalam penularan dari kelompok berisiko tinggi (wanita penjaja seks) pada kelompok berisiko rendah yaitu istri-istri mereka (Riono, 1999).

Dari 624 responden, sekitar seperempatnya $(24,7 \%)$ yang mencari pertolongan medis untuk mengatasi masalah $(59,3 \%)$ dan melakukan pengobatan sendiri $(74,2 \%)$. Setelah mencari pertolongan medis baru kemudian melakukan pengobatan sendiri (beli obat sendiri, ke dukun, menggunakan ramuan tradisional). Tahap-tahap pencarian pengobatan ini sesuai dengan hasil penelitian kualitatif di Jakarta Utara, dimana lebih dari seperempat responden di pelabuhan $(n=22)$, mengakui pernah sakit PMS. Tahap-tahap pencarian pengobatan ini berbeda menurut jenis penyakit kelamin (Kresno, 2001).

Sedangkan responden yang melakukan upaya pengobatan sendiri sebesar 74,2\%. Upaya untuk mengurangi gejala sakit ini sejalan dengan penelitian kualitatif di Jakarta Utara di mana mereka membeli obat antibiotik di warung atau toko obat seperti teramycin $500 \mathrm{mg}$ selama 5-7 hari dan baru berobat ke dokter bila tidak sembuh (Kresno, 2001). Oleh sebab itu besar kemungkinan responden menggunakan obat yang tidak tepat dan tidak sesuai dengan dosisnya sehingga perlu mendapat perhatian serius, karena dapat menimbulkan resistensi obat. Bertindak mengobati sendiri disebabkan sudah percaya kepada diri sendiri, dan meyakini akan mendapatkan kesembuhan (Notoatmodjo,1993).

Responden yang memanfaatkan pengobatan tradisional kemungkinan mengharapkan pengobatan yang lebih dari sekedar mendapat obat dan merasa kebutuhannya dapat terpenuhi. Pada umumnya masyarakat dalam mencari pertolongan kesehatan memanfaatkan pengobatan tradisional sebagai salah satu pilihannya. Dimulai dengan mencoba mengobati sendiri kemudian baru meminta pertolongan dukun. Hasilnya akan jauh lebih baik daripada tidak mengobati sama sekali (Soesilo,1992).

Di samping itu responden yang mencari pertolongan medis $(59,3 \%)$, kemungkinan disebabkan pada tahap peran sakit tidak ada kemajuan bila hanya mengobati sendiri (Kasl \& Cobb, 1983 dalam Becker \& Maiman,1983). Tidak adanya data tentang faktor-faktor yang menghambat dan mendorong individu untuk berobat ke pelayanan kesehatan pada penelitian ini, diasumsikan merupakan faktor keseriusan penyakit dan pelayanan kesehatan yang 
memuaskan. Pria pada umumnya sama dengan wanita dalam mengharapkan pelayanan kesehatan, yaitu terjaganya privacy, tenaga kesehatan yang mengerti dan menjaga rahasia. Faktor jarak, petugas yang simpatik, tidak judes, biaya terjangkau akan mendorong mereka datang ke fasilitas kesehatan (Notoatmodjo,1993).

Variabel yang berhubungan dengan perilaku pencarian pengobatan kurang baik adalah pendidikan $(\mathrm{OR}=1,6252)$ dan pengetahuan $(\mathrm{OR}=$ 1,7607), artinya responden tidak akan berobat apabila ia kurang mendapatkan informasi berupa pengetahuan tentang AIDS dan tidak didukung dengan pendidikan yang memadai, di mana pendidikan merupakan salah satu faktor yang cukup kuat berpengaruh terhadap tingkat pengetahuan seseorang.

Pengelompokkan umur tidak mempengaruhi dalam perilaku pencarian pengobatan. Hasil yang menggambarkan hal yang serupa (Wuryaningsih, 1997) yaitu tidak ada hubungan antara umur dengan perilaku pencarian pengobatan. Meskipun demikian, semakin muda dan kurang pengalaman saja tidak cukup mempengaruhi responden untuk tidak melakukan pencarian pengobatan, hal ini perlu didukung oleh faktor pengetahuan yang kurang mengenai penyakit dan pendidikan yang rendah. Model demografi menyebutkan hal yang sama di mana umur merupakan salah satu variabel yang mempengaruhi tindakan untuk berobat (Wolansky, 1980). Hasil yang hampir sama terdapat pada studi yang dilakukan Israelski, et al (2001) di USA menunjukkan umur yang lebih tua mempengaruhi kepatuhan pasien untuk datang ke pelayanan kesehatan.

Responden yang berstatus kawin $(64,3 \%)$ menyatakan pernah melakukan hubungan seks dengan wanita penjaja seks. Besar kemungkinan $(79,1 \%)$ mengalami penyakit kelamin sehingga dapat menularkan PMS-HIV/AIDS kepada keluarganya. Dengan menggunakan asumsi, semakin banyak seseorang memiliki pasangan seks akan semakin tinggi kemungkinan mereka menemukan pasangan yang sudah mengidap PMSHIV/AIDS, semakin tinggi pula untuk tertular penyakit kelamin. Dari hasil uji beda proporsi dengan chi-square, tidak terlihat adanya hubungan yang bermakna antara yang belum kawin dengan perilaku pencarian pengobatan kurang baik $(\mathrm{p}=0,119)$. Hasil yang hampir sama pada penelitian Rizon (1993) menunjukkan status perkawinan tidak berhubungan secara bermakna dengan perilaku seksual $(p>0,05)$ pada supir truk. Hasil penelitian ini juga berbeda dengan teori yang dikemukakan Wolansky (1980), di mana pendekatan ini bertumpu pada asumsi seseorang yang mempunyai latar belakang tertentu

(kawin atau belum kawin) akan memiliki pandangan tersendiri mengenai pengobatan.

Responden yang berpendidikan rendah lebih banyak tidak mencari pengobatan dibandingkan dengan yang berpendidikan tinggi. Dengan kata lain semakin rendah pendidikan maka semakin kecil kemungkinan untuk mencari pengobatan. Tingkat pendidikan seseorang sangat erat berkaitan dengan tingkat intelektualitas. Semakin rendah pendidikan, diasumsikan akan sulit menggunakan logika berfikir dalam memahami suatu informasi yang didapat. Dalam masalah PMS-HIV/AIDS, responden dengan tingkat pendidikan yang lebih rendah akan semakin negatif dalam berperilaku terutama dalam hal mencari pengobatan.

Pengetahuan responden diukur dari pengetahuan mendasar terhadap AIDS, dan 1,4\% tidak pernah mendengar tentang HIV/AIDS. Masih adanya responden yang belum pernah mendengar tentang HIV/AIDS, meskipun HIV/ AIDS sudah ditemukan di Indonesia 13 tahun yang lalu, menyebabkan berbagai pihak harus tetap waspada. Secara presentase, kelihatan responden yang mempunyai pengetahuan tentang AIDS cukup besar namun masih banyak hal-hal yang cukup prinsip sekali yang belum mereka ketahui 
memuaskan. Pria pada umumnya sama dengan wanita dalam mengharapkan pelayanan kesehatan, yaitu terjaganya privacy, tenaga kesehatan yang mengerti dan menjaga rahasia. Faktor jarak, petugas yang simpatik, tidak judes, biaya terjangkau akan mendorong mereka datang ke fasilitas kesehatan (Notoatmodjo,1993).

Variabel yang berhubungan dengan perilaku pencarian pengobatan kurang baik adalah pendidikan $(\mathrm{OR}=1,6252)$ dan pengetahuan $(\mathrm{OR}=$ 1,7607), artinya responden tidak akan berobat apabila ia kurang mendapatkan informasi berupa pengetahuan tentang AIDS dan tidak didukung dengan pendidikan yang memadai, di mana pendidikan merupakan salah satu faktor yang cukup kuat berpengaruh terhadap tingkat pengetahuan seseorang.

Pengelompokkan umur tidak mempengaruhi dalam perilaku pencarian pengobatan. Hasil yang menggambarkan hal yang serupa (Wuryaningsih, 1997) yaitu tidak ada hubungan antara umur dengan perilaku pencarian pengobatan. Meskipun demikian, semakin muda dan kurang pengalaman saja tidak cukup mempengaruhi responden untuk tidak melakukan pencarian pengobatan, hal ini perlu didukung oleh faktor pengetahuan yang kurang mengenai penyakit dan pendidikan yang rendah. Model demografi menyebutkan hal yang sama di mana umur merupakan salah satu variabel yang mempengaruhi tindakan untuk berobat (Wolansky, 1980). Hasil yang hampir sama terdapat pada studi yang dilakukan Israelski, et al (2001) di USA menunjukkan umur yang lebih tua mempengaruhi kepatuhan pasien untuk datang ke pelayanan kesehatan.

Responden yang berstatus kawin $(64,3 \%)$ menyatakan pernah melakukan hubungan seks dengan wanita penjaja seks. Besar kemungkinan $(79,1 \%)$ mengalami penyakit kelamin sehingga dapat menularkan PMS-HIV/AIDS kepada keluarganya. Dengan menggunakan asumsi, semakin banyak seseorang memiliki pasangan seks akan semakin tinggi kemungkinan mereka menemukan pasangan yang sudah mengidap PMSHIV/AIDS, semakin tinggi pula untuk tertular penyakit kelamin. Dari hasil uji beda proporsi dengan chi-square, tidak terlihat adanya hubungan yang bermakna antara yang belum kawin dengan perilaku pencarian pengobatan kurang baik $(\mathrm{p}=0,119)$. Hasil yang hampir sama pada penelitian Rizon (1993) menunjukkan status perkawinan tidak berhubungan secara bermakna dengan perilaku seksual $(p>0,05)$ pada supir truk. Hasil penelitian ini juga berbeda dengan teori yang dikemukakan Wolansky (1980), di mana pendekatan ini bertumpu pada asumsi seseorang yang mempunyai latar belakang tertentu

(kawin atau belum kawin) akan memiliki pandangan tersendiri mengenai pengobatan.

Responden yang berpendidikan rendah lebih banyak tidak mencari pengobatan dibandingkan dengan yang berpendidikan tinggi. Dengan kata lain semakin rendah pendidikan maka semakin kecil kemungkinan untuk mencari pengobatan. Tingkat pendidikan seseorang sangat erat berkaitan dengan tingkat intelektualitas. Semakin rendah pendidikan, diasumsikan akan sulit menggunakan logika berfikir dalam memahami suatu informasi yang didapat. Dalam masalah PMS-HIV/AIDS, responden dengan tingkat pendidikan yang lebih rendah akan semakin negatif dalam berperilaku terutama dalam hal mencari pengobatan.

Pengetahuan responden diukur dari pengetahuan mendasar terhadap AIDS, dan 1,4\% tidak pernah mendengar tentang HIV/AIDS. Masih adanya responden yang belum pernah mendengar tentang HIV/AIDS, meskipun HIV/ AIDS sudah ditemukan di Indonesia 13 tahun yang lalu, menyebabkan berbagai pihak harus tetap waspada. Secara presentase, kelihatan responden yang mempunyai pengetahuan tentang AIDS cukup besar namun masih banyak hal-hal yang cukup prinsip sekali yang belum mereka ketahui 
secara benar. Hal ini menunjukkan bahwa informasi yang didapat hanya bersifat umum.

Sumber informasi yang dapat dijangkau responden adalah televisi, radio, surat kabar dan majalah. Informasi tentang HIV/AIDS, pada umumnya diperoleh responden berasal lebih dari satu sumber. Televisi dengan urutan pertama $(57,9 \%)$, diikuti dengan surat kabar $(49,8 \%)$, radio $(36,7 \%)$, dan majalah $(27,9 \%)$.

Hal ini serupa dengan penelitian yang dilakukan oleh Pudjono, et al (1996), 82\% responden berpendapat surat kabar dan televisi merupakan media yang tepat untuk menginformasikan pencegahan AIDS. Demikian pula hasil penelitian Priotomo, et al (1992), televisi menjadi sumber informasi pertama mengenai AIDS $(80,4 \%)$ diikuti surat kabar $(74,2 \%)$. Besarnya peranan televisi dalam menyampaikan informasi tentang AIDS dapat dimaklumi, karena media ini di samping berskala nasional, sekaligus menjadi media hiburan yang banyak diminati di berbagai pelosok tanah air.

\section{KESIMPULAN}

Proporsi perilaku pencarian pengobatan kurang baik pada pria dengan PMS-HIV/AIDS di Jakarta, Surabaya dan Menado sebesar 24,7\%. Sebagian besar responden berumur $<31$ tahun $(58,8 \%)$ dan lebih dari sepertiga responden menyatakan belum kawin (35,7\%). Di samping itu, sepertiga responden berpendidikan rendah $(33,5 \%)$ dan sebagian besar responden berpengetahuan kurang tentang AIDS $(54,5 \%)$ serta sebagian besar responden belum pernah kontak dengan media tentang AIDS $(55,13 \%)$.

Tidak ada hubungan yang bermakna antara umur muda dengan perilaku pencarian pengobatan kurang baik, dan antara responden yang belum kawin dengan perilaku pencarian pengobatan kurang baik $(p>0,05)$. Ada hubungan yang bermakna antara pendidikan rendah dengan perilaku pencarian pengobatan kurang baik dan antara pengetahuan kurang tentang AIDS dengan perilaku pencarian pengobatan kurang baik $(\mathrm{p}<0,05)$. Tidak ada hubungan yang bermakna antara yang belum pernah kontak media tentang AIDS dengan perilaku pencarian pengobatan kurang baik $(\mathrm{p}<0,05)$. Responden yang berpengetahuan kurang berpeluang 1,760 kali (95\% CI 1,1724-2,6442) untuk melakukan pencarian pengobatan kurang baik dibandingkan dengan responden yang berpengetahuan baik setelah dikontrol variabel pendidikan. Responden yang berpendidikan rendah berpeluang 1,625 kali (95\% CI 1,0236-2,5805) untuk melakukan pencarian pengobatan kurang baik dibandingkan responden yang berpendidikan tinggi setelah dikontrol variabel pengetahuan.

Saran untuk mengetahui perilaku pencarian pengobatan yang lebih komprehensif adalah perlunya melakukan penelitian selanjutnya secara kualitatif mengingat tingginya presentase responden yang tidak melakukan pencarian pengobatan, sehingga bisa diketahui lebih dalam dan lebih jauh alasan responden tidak melakukan pencarian pengobatan. Untuk program penyuluhan, perlu dilakukan upaya peningkatan program kerja sama yang berkesinambungan dan terintegrasi mulai dari Dinas Kesehatan, DPRD, Rumah Sakit, Dokter, tenaga kesehatan lain dan LSM, dimulai dari kampanye pencegahan PMS-HIV/AIDS melalui publikasi poster-poster, leaflet, buku panduan ke kapal, pelabuhan dan terminal sampai dengan cara pendekatan peer group pressure (lewat teman sekerja). Meningkatkan pemantauan dan evaluasi program penyuluhan kesehatan dengan menggunakan kuesioner untuk uji awal dan uji akhir guna memperkirakan perkembangan pengetahuan, sikap dan perilaku kelompok pria tersebut. (ENT).

* Efy Afifah, SKp., M.Kes: Staf Akademik Kelompok Keilmuan Dasar Keperawatan dan Keperawatan Dasar Fakultas Ilmu Keperawatan Universitas Indonesia. 
secara benar. Hal ini menunjukkan bahwa informasi yang didapat hanya bersifat umum.

Sumber informasi yang dapat dijangkau responden adalah televisi, radio, surat kabar dan majalah. Informasi tentang HIV/AIDS, pada umumnya diperoleh responden berasal lebih dari satu sumber. Televisi dengan urutan pertama $(57,9 \%)$, diikuti dengan surat kabar $(49,8 \%)$, radio $(36,7 \%)$, dan majalah $(27,9 \%)$.

Hal ini serupa dengan penelitian yang dilakukan oleh Pudjono, et al (1996), 82\% responden berpendapat surat kabar dan televisi merupakan media yang tepat untuk menginformasikan pencegahan AIDS. Demikian pula hasil penelitian Priotomo, et al (1992), televisi menjadi sumber informasi pertama mengenai AIDS $(80,4 \%)$ diikuti surat kabar $(74,2 \%)$. Besarnya peranan televisi dalam menyampaikan informasi tentang AIDS dapat dimaklumi, karena media ini di samping berskala nasional, sekaligus menjadi media hiburan yang banyak diminati di berbagai pelosok tanah air.

\section{KESIMPULAN}

Proporsi perilaku pencarian pengobatan kurang baik pada pria dengan PMS-HIV/AIDS di Jakarta, Surabaya dan Menado sebesar 24,7\%. Sebagian besar responden berumur $<31$ tahun $(58,8 \%)$ dan lebih dari sepertiga responden menyatakan belum kawin (35,7\%). Di samping itu, sepertiga responden berpendidikan rendah $(33,5 \%)$ dan sebagian besar responden berpengetahuan kurang tentang AIDS $(54,5 \%)$ serta sebagian besar responden belum pernah kontak dengan media tentang AIDS $(55,13 \%)$.

Tidak ada hubungan yang bermakna antara umur muda dengan perilaku pencarian pengobatan kurang baik, dan antara responden yang belum kawin dengan perilaku pencarian pengobatan kurang baik $(p>0,05)$. Ada hubungan yang bermakna antara pendidikan rendah dengan perilaku pencarian pengobatan kurang baik dan antara pengetahuan kurang tentang AIDS dengan perilaku pencarian pengobatan kurang baik $(\mathrm{p}<0,05)$. Tidak ada hubungan yang bermakna antara yang belum pernah kontak media tentang AIDS dengan perilaku pencarian pengobatan kurang baik $(\mathrm{p}<0,05)$. Responden yang berpengetahuan kurang berpeluang 1,760 kali (95\% CI 1,1724-2,6442) untuk melakukan pencarian pengobatan kurang baik dibandingkan dengan responden yang berpengetahuan baik setelah dikontrol variabel pendidikan. Responden yang berpendidikan rendah berpeluang 1,625 kali (95\% CI 1,0236-2,5805) untuk melakukan pencarian pengobatan kurang baik dibandingkan responden yang berpendidikan tinggi setelah dikontrol variabel pengetahuan.

Saran untuk mengetahui perilaku pencarian pengobatan yang lebih komprehensif adalah perlunya melakukan penelitian selanjutnya secara kualitatif mengingat tingginya presentase responden yang tidak melakukan pencarian pengobatan, sehingga bisa diketahui lebih dalam dan lebih jauh alasan responden tidak melakukan pencarian pengobatan. Untuk program penyuluhan, perlu dilakukan upaya peningkatan program kerja sama yang berkesinambungan dan terintegrasi mulai dari Dinas Kesehatan, DPRD, Rumah Sakit, Dokter, tenaga kesehatan lain dan LSM, dimulai dari kampanye pencegahan PMS-HIV/AIDS melalui publikasi poster-poster, leaflet, buku panduan ke kapal, pelabuhan dan terminal sampai dengan cara pendekatan peer group pressure (lewat teman sekerja). Meningkatkan pemantauan dan evaluasi program penyuluhan kesehatan dengan menggunakan kuesioner untuk uji awal dan uji akhir guna memperkirakan perkembangan pengetahuan, sikap dan perilaku kelompok pria tersebut. (ENT).

* Efy Afifah, SKp., M.Kes: Staf Akademik Kelompok Keilmuan Dasar Keperawatan dan Keperawatan Dasar Fakultas Ilmu Keperawatan Universitas Indonesia. 


\section{KEPUSTAKAAN}

Akinawo, E.O \& Oguntimehin, F. (1997, April 3 ). Health-seeking behaviour of STD patients in an urban area of southwest nigeria: An Exploratory Study, in Health Transition Review. Supplement to Volume 7, 307-313. Available: Http://inceph.anu.edu.au/htc/ dapdfs/Akkinawo3.pdf Anonimous. (2002, April 20). Health seeking behaviour and STDs. Available: Http://www.std services.on:net/std/social_aspects/ health_seek.htm.

Ariawan, I. (1998).Besar dan metode sampel pada penelitian kesehatan. Jurusan Biostatistik. Jakarta: FKM UI

Agoes, A., \& Jacob,T (ed). Pengobatan Tradisional (I). Jakarta: Penerbit buku kedokteran EGC

Becker, M.H., \& Maiman, L.A.(1983). Models of health related behavior, dalam: Mechanic,D (Eds.), Handbook of health care and the health professions. New York: The Free Press

Departemen Kesehatan RI. (1997). Himpunan peraturan perundang-undangan tentang penanggulangan HIV/AIDS. Jakarta: Pusat PKM Depkes RI

Departemen Kesehatan RI. (2002). Data laporan pengidap infeksi HIV dan kasus AIDS sampai dengan 30 Juni 2002. Jakarta: Ditjen PPM \& PL Depkes RI

Fahmi, S. (2001). Penyakit menular seksual. Jakarta: Balai penerbit FKUI

Israelski, D.et.al.(2001, March 10). Sociodemographic characteristics associated with medical appointment adherence among $H I V$-seropositive patients seeking treatment in a country outpatient facility, Nov:33 (5)470-5. Available:

H t t p: / / w w w. n c b i ... / query.fcgi?cmd=Retrieve \&db+Pubmed\&list $\underline{\text { uids }=116765892 \mathrm{dopt}=\mathrm{Abstrac}}$
Kresno, S. (2001). Penilaian cepat perilaku mencari pengobatan pada penderita penyakit menular seksual (PMS) di Jakarta. Jakarta: DepKes RI-FKM UI.

Muninjaya, A. A.G. (1998). AIDS di Indonesia, masalah dan kebijakan penanggulangannya, Jakarta: Penerbit Buku Kedokteran EGC

Notoatmodjo, S. (1993). Pengantar pendidikan kesehatan dan ilmu perilaku kesehatan. Yogyakarta: Andi Offset

Priotomo, Y, et al. (1992). Pengetahuan, sikap, prap, praktek wanita pemijat dan pengelola panti pijat terhadap AIDS di wilayah DKI Jakarta Selatan. Depok: Puslitkes LPUI

Pudjono, R. B, et al. (1996). Studimengenai media penyampaian informasi yang tepat/sesuai kepada kelompok remaja dalam upaya pencegahan AIDS di Depok, Jawa Barat. Depok: Puslitkes LPUI

Riono, P. (1999). Masalah epidemi infeksi menular seksual \& HIV/AIDS. Makalah dipresentasikan pada Pelatihan Deteksi \& Monitoring PMS, HIV/AIDS di Indonesia.

Rizon, I. (1993). Pengetahuan, sikap \& perilaku seksual pengemudi bus antar kota jarak jauh terhadap resiko tertular HIV/AIDS.

Skripsi FKM UI, Depok.Tidak diterbitkan Rosentock, et al. (1994). The Health belief model and HIV risk behavior change dalam Preventing AIDS: theory and method of behavior intervention. New York: Planum Press

Soesilo, S. (1992). Peranan jamu dan obat tradisional dalam pelayanan kesehatan masyarakat dalam Agoes, A.\& Jacob, $T(E d)$. Pengobatan Tradisional (I). Jakarta: Penerbit

Buku Kedokteran EGC.Supriyanti, I. (1999). Perilaku seksual dan pengetahuan pelaut mengenai HIV/AIDS di Bali, Kupang dan Ujung Pandang tahun 1998 (Analisis Data Sekunder AusAid 1998). 


\section{KEPUSTAKAAN}

Akinawo, E.O \& Oguntimehin, F. (1997, April 3 ). Health-seeking behaviour of STD patients in an urban area of southwest nigeria: An Exploratory Study, in Health Transition Review. Supplement to Volume 7, 307-313. Available: Http://inceph.anu.edu.au/htc/ dapdfs/Akkinawo3.pdf Anonimous. (2002, April 20). Health seeking behaviour and STDs. Available: Http://www.std services.on:net/std/social_aspects/ health_seek.htm.

Ariawan, I. (1998).Besar dan metode sampel pada penelitian kesehatan. Jurusan Biostatistik. Jakarta: FKM UI

Agoes, A., \& Jacob,T (ed). Pengobatan Tradisional (I). Jakarta: Penerbit buku kedokteran EGC

Becker, M.H., \& Maiman, L.A.(1983). Models of health related behavior, dalam: Mechanic,D (Eds.), Handbook of health care and the health professions. New York: The Free Press

Departemen Kesehatan RI. (1997). Himpunan peraturan perundang-undangan tentang penanggulangan HIV/AIDS. Jakarta: Pusat PKM Depkes RI

Departemen Kesehatan RI. (2002). Data laporan pengidap infeksi HIV dan kasus AIDS sampai dengan 30 Juni 2002. Jakarta: Ditjen PPM \& PL Depkes RI

Fahmi, S. (2001). Penyakit menular seksual. Jakarta: Balai penerbit FKUI

Israelski, D.et.al.(2001, March 10). Sociodemographic characteristics associated with medical appointment adherence among $H I V$-seropositive patients seeking treatment in a country outpatient facility, Nov:33 (5)470-5. Available:

H t t p: / / w w w. n c b i ... / query.fcgi?cmd=Retrieve \&db+Pubmed\&list $\underline{\text { uids }=116765892 \mathrm{dopt}=\mathrm{Abstrac}}$
Kresno, S. (2001). Penilaian cepat perilaku mencari pengobatan pada penderita penyakit menular seksual (PMS) di Jakarta. Jakarta: DepKes RI-FKM UI.

Muninjaya, A. A.G. (1998). AIDS di Indonesia, masalah dan kebijakan penanggulangannya, Jakarta: Penerbit Buku Kedokteran EGC

Notoatmodjo, S. (1993). Pengantar pendidikan kesehatan dan ilmu perilaku kesehatan. Yogyakarta: Andi Offset

Priotomo, Y, et al. (1992). Pengetahuan, sikap, prap, praktek wanita pemijat dan pengelola panti pijat terhadap AIDS di wilayah DKI Jakarta Selatan. Depok: Puslitkes LPUI

Pudjono, R. B, et al. (1996). Studimengenai media penyampaian informasi yang tepat/sesuai kepada kelompok remaja dalam upaya pencegahan AIDS di Depok, Jawa Barat. Depok: Puslitkes LPUI

Riono, P. (1999). Masalah epidemi infeksi menular seksual \& HIV/AIDS. Makalah dipresentasikan pada Pelatihan Deteksi \& Monitoring PMS, HIV/AIDS di Indonesia.

Rizon, I. (1993). Pengetahuan, sikap \& perilaku seksual pengemudi bus antar kota jarak jauh terhadap resiko tertular HIV/AIDS.

Skripsi FKM UI, Depok.Tidak diterbitkan Rosentock, et al. (1994). The Health belief model and HIV risk behavior change dalam Preventing AIDS: theory and method of behavior intervention. New York: Planum Press

Soesilo, S. (1992). Peranan jamu dan obat tradisional dalam pelayanan kesehatan masyarakat dalam Agoes, A.\& Jacob, $T(E d)$. Pengobatan Tradisional (I). Jakarta: Penerbit

Buku Kedokteran EGC.Supriyanti, I. (1999). Perilaku seksual dan pengetahuan pelaut mengenai HIV/AIDS di Bali, Kupang dan Ujung Pandang tahun 1998 (Analisis Data Sekunder AusAid 1998). 
Skripsi FKM UI, Depok. Tidak diterbitkan Suryadi, C. (2001). Prevalensi PMS pada pekerja seks komersial di Jakarta, Surabaya dan Manado serta peran pria sebagai provider dan pasien. Makalah dipresentasikan pada Seminar Sehari Peningkatan Peran dan Tanggung Jawab Laki-laki Dalam Upaya Menghambat Epidemi HIV/AIDS Di Indonesia Depkes- DepSos. Jakarta.

Utomo B. et.al. (1966-2000). Findings of BSS on female commercial sex workers and adult male respondents. Jakarta: Center for Health Research University of Indonesia.
Waldrun, I. (1986). Why do women live longer than men?, dalam Conrad, P \& Kern, R (Eds), The Sociology of health and illness. New York: St M ${ }^{\text {artin }}$, s Press.

Wolansky, F.D. (1980). The sociology of health principles, profession and issues. U S A : Little.

Brown Company.Wuryaningsih, C. E. (1997). Perilaku pencarian pengobatan pada wanita dengan penyakit hubungan seksual dari hasil pap smear di klinik pisangan baru tahun 1994. Tesis Program Studi Ilmu Kesehatan Masyarakat. FKM-UI Depok.Tidak diterbitkan

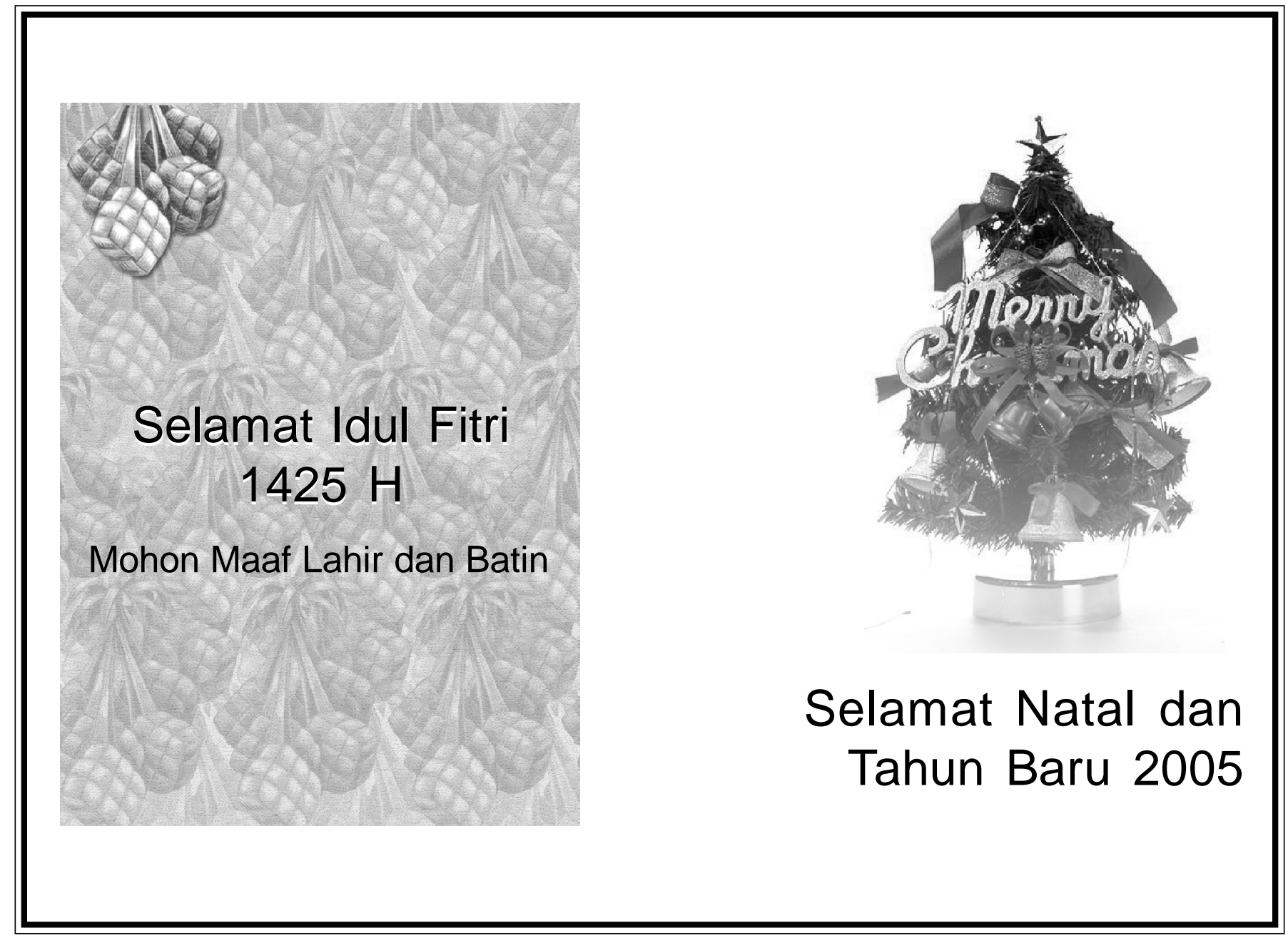


Skripsi FKM UI, Depok. Tidak diterbitkan Suryadi, C. (2001). Prevalensi PMS pada pekerja seks komersial di Jakarta, Surabaya dan Manado serta peran pria sebagai provider dan pasien. Makalah dipresentasikan pada Seminar Sehari Peningkatan Peran dan Tanggung Jawab Laki-laki Dalam Upaya Menghambat Epidemi HIV/AIDS Di Indonesia Depkes- DepSos. Jakarta.

Utomo B. et.al. (1966-2000). Findings of BSS on female commercial sex workers and adult male respondents. Jakarta: Center for Health Research University of Indonesia.
Waldrun, I. (1986). Why do women live longer than men?, dalam Conrad, P \& Kern, R (Eds), The Sociology of health and illness. New York: St M ${ }^{\text {artin }}$, s Press.

Wolansky, F.D. (1980). The sociology of health principles, profession and issues. U S A : Little.

Brown Company.Wuryaningsih, C. E. (1997). Perilaku pencarian pengobatan pada wanita dengan penyakit hubungan seksual dari hasil pap smear di klinik pisangan baru tahun 1994. Tesis Program Studi Ilmu Kesehatan Masyarakat. FKM-UI Depok.Tidak diterbitkan

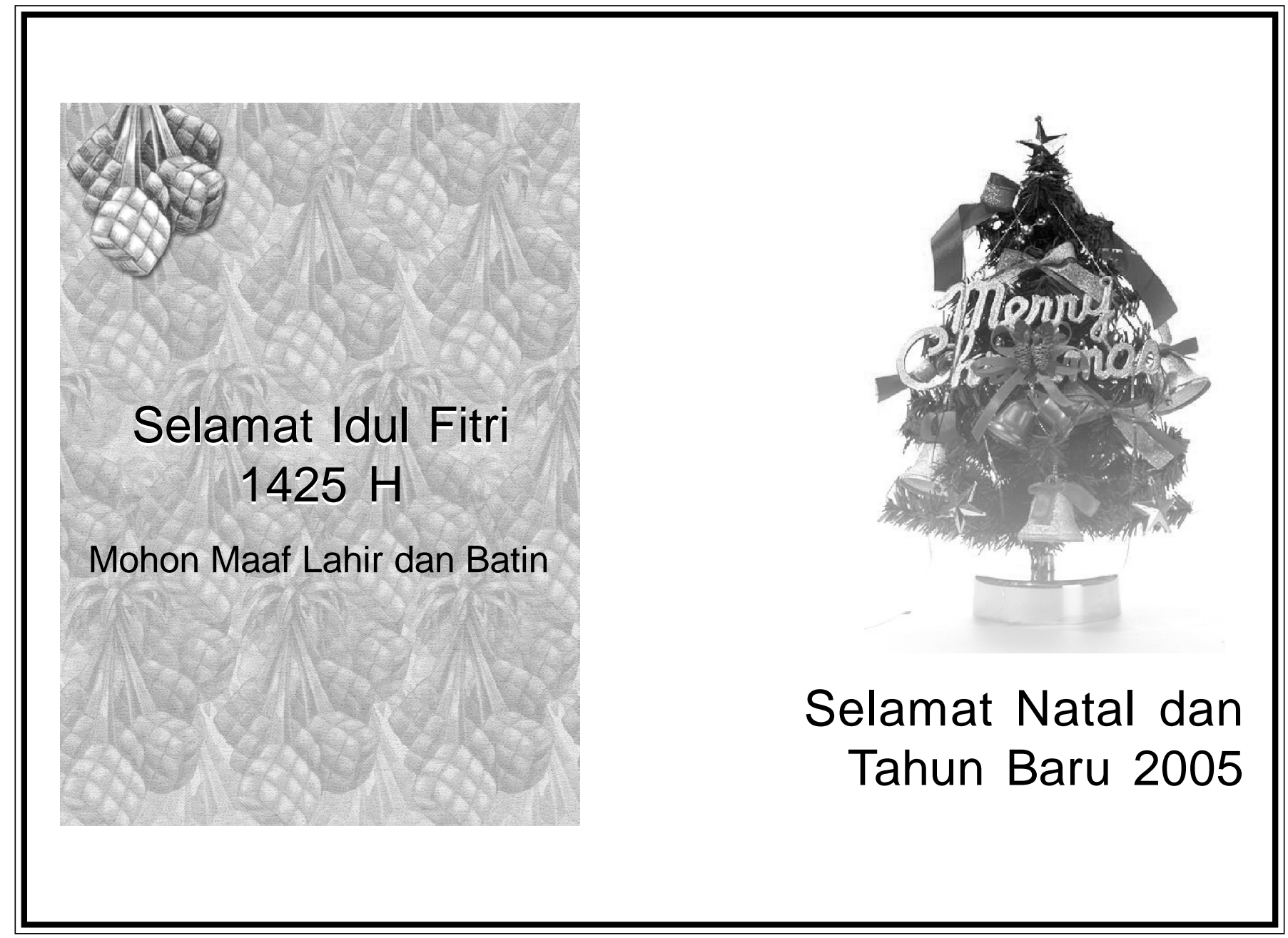

